\section{PRODUCTION OF LIPID AND CARBOHYDRATE IN Tetradesmus obliquUs UPSI-JRM02 UNDER NITROGEN STRESS CONDITION}

\author{
Syafiqah Md Nadzira, Norjan Yusofa, Norazela Nordina, Azlan \\ Kamarib, Mohd Zulkhairi Mohd Yusoffc
}

aDepartment of Biology, Faculty of Science and Mathematics, Universiti Pendidikan Sultan Idris, 35900, Tanjung Malim, Perak, Malaysia

bDepartment of Chemistry, Faculty of Science and Mathematics, Universiti Pendidikan Sultan Idris, 35900, Tanjung Malim, Perak, Malaysia

cDepartment of Bioprocess Technology, Faculty of Biotechnology and Biomolecular Sciences, Universiti Putra Malaysia, 43400 Serdang, Selangor, Malaysia
Article history

Received

16 May 2019

Received in revised form

16 December 2020

Accepted

5 January 2021

Published online

23 February 2021

*Corresponding author norjan@fsmt.upsi.edu.my

\section{Graphical abstract}

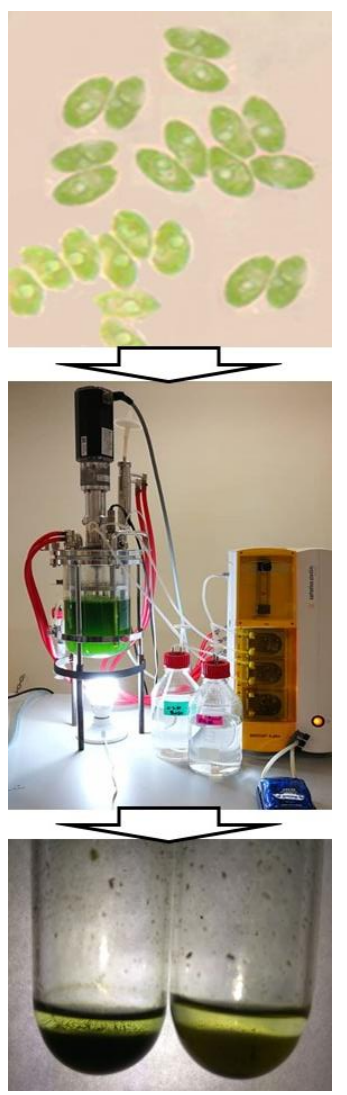

\begin{abstract}
Nitrogen stress condition is believed to increase the production of lipid in microalgae, but the synthesis of both lipid and carbohydrate is less known. Therefore, the effect of nitrogen stress condition on the synthesis of lipid and carbohydrate of Tetradesmus obliquUS UPSIJRM02 was studied in a $2 \mathrm{~L}$ bioreactor system. The highest lipid and carbohydrate yields achieved under nitrogen stress condition were $37 \%$ and $23 \%$, respectively. Nitrogen stress condition induced the accumulation of carbohydrate at early stage but started to reduce on day 4 when the carbon shifted towards lipid production. The fatty acid profile produced under nitrogen stress condition was composed of $54 \%$ polyunsaturated fatty acid (PUFA), 43\% saturated fatty acid (SFA) and 3\% monounsaturated fatty acid (MUFA). The biofuel properties of $T$. obliquus obtained under the nitrogen stress condition was within the range of biodiesel standard and is most suitable for the usage in cold country.
\end{abstract}

Keywords: Nitrogen stress, Tetradesmus obliquus, lipid, carbohydrate, biofuel

\begin{abstract}
Abstrak
Keadaan stres nitrogen dipercayai dapat meningkatkan penghasilan lipid dalam mikroalga, tetapi sintesis kedua-dua lipid dan karbohidrat kurang diketahui. Oleh itu, kesan keadaan stres nitrogen terhadap sintesis lipid dan karbohidrat Tetradesmus obliquUs UPSIJRM02 telah dikaji dalam sistem reaktor bio 2 L. Hasil lipid tertinggi dan karbohidrat yang dicapai di bawah keadaan stres nitrogen adalah $37 \%$ dan $23 \%$, masing-masing. Keadaan stres nitrogen mengaruh pengumpulan karbohidrat pada peringkat awal tetapi mula menurun pada hari ke-4 apabila karbon beralih ke arah penghasilan lipid. Profil asid lemak yang dihasilkan di bawah keadaan stres nitrogen terdiri daripada $54 \%$ asid lemak poli tak tepu (PUFA), $43 \%$ asid lemak tepu (SFA) dan 3\% asid lemak mono tak tepu (MUFA). Sifat bahan bakar bio $T$. obliquus yang diperolehi di bawah keadaan stres nitrogen berada dalam julat piawai biodiesel dan paling sesuai untuk kegunaan di negara sejuk.
\end{abstract}

Kata kunci: Stres nitrogen, Tetradesmus obliquus, lipid, karbohidrat, bahan bakar bio

(C) 2021 Penerbit UTM Press. All rights reserved 


\subsection{INTRODUCTION}

Microalgae consist of simple unicellular structure which have more potential as sustainable biofuel compared to the first and second generations of biofuel. The first generation of biofuel was produced from edible crops where it competes with the agriculture industries making it unsustainable. Meanwhile, the second generation was produced from non-edible plant material but the pre-treatment to produce biofuel is high due to the composition of lignin, cellulose and hemicellulose. Microalgae show rapid growth, thus enabling many species to produce high lipid contents of $20-50 \%$ biomass dry weight [1]. They are also able to produce ten times more oil compared to plants, due to their higher lipid content and biomass. In addition, cultivation of microalgae can be performed using wastewater with high nitrogen contents, such as ammonium and nitrate [2] thus helping to reduce water pollution.

Microalgae growth depends on various factors such as nitrogen sources, light intensity, temperature, $\mathrm{pH}$ and others (salinity, carbon dioxide, trace metal, photoperiod and phosphorus). These factors influence the growth rates, productivity and biomass composition of the microalgae. In nature, microalgae are exposed to various environmental factors that results in difference physiology and growth response. In general, the production of lipid and carbohydrate in microalgae can be enhanced by manipulating the environmental (light, salinity, and temperature) and nutritional (phosphorus, trace element, and nitrogen) factors [3]. In which among these factors the most noteworthy to increase the production of lipid and carbohydrate are nitrogen stress. Brever et al. [4] stated that under nitrogen stress condition microalgae lipid and carbohydrate are accumulated simultaneously. Microalgae that are cultured in nitrogen sufficient condition produce a small amount of triacyl glycerides (TAG) but the content of TAG increased when the microalgae is grown in a nitrogen limited condition [5]. Under nitrogen stress, lipid is accumulated due to catabolism of amino acids that produces various tricarboxylic acid (TCA) cycle intermediates, such as acetyl COA for fatty acid elongation [6, 7, \& 8]. Nitrogen stress is believed to have a significance effect on microalgae lipid or carbohydrate productivity leading to a conclusion that the reaction might depend on the microalgae species [9].

Choosing the suitable microalgae strain is important to increase microalgae biofuel production as different microalgae species exhibited varying biochemicals content when cultivated under different culture conditions. The composition and metabolism of microalgae lipid and carbohydrate are species dependent. The production of lipid content from various species of microalgae was in the range of 5-75\% [10]. However different microalgae species exhibited varying lipid content when cultivated under different culture conditions.
There were many microalgae strains reported to be capable of producing lipid, such as Botryococcus braunii, Chlamydomonas pitschmannii, Chlorella vulgaris and Nannochloropsis sp., with lipid content ranges of $25-75 \%, 51 \%, 5-58 \%$ and $12-53 \%$, respectively [10]. The carbohydrate content in microalgae also varies according to species, such as in Chlorella vulgaris (37-55\%) [1] Chlamydomonas reinhardtii (9.2\%) [11] and Chlorococum sp. (32.5\%) [1]. Microalgae biomass, particularly lipid and carbohydrate, is useful as a feedstock for the production of biodiesel, bioethanol, biohydrogen and bio-oil [12].

Sequential accumulation of starch and lipid was shown in a study on Chlorella sorokiniana with starch as predominant carbon storage under short term nitrogen depletion condition, before the carbon shifted towards lipid production [13]. Meanwhile, previous studies of Tetradesmus sp. were mainly focused on lipid production alone, instead of both lipid and carbohydrates $[6,8]$. By contrast, this study focuses on both macromolecules, which is crucial as lipid and carbohydrate share the same fixed carbon precursor from photosynthesis. In addition, changes of lipid and carbohydrate yields under nitrogen stress are important to be understand in exploiting both biomolecules for production of biofuel. Therefore, this study aims to examine the production of lipid and carbohydrate in Tetradesmus obliquUs UPSI-JRM02 under nitrogen stress condition.

\subsection{METHODOLOGY}

\subsection{Microalgae Strain and Culture}

The T. obliquus UPSI-JRM02 was isolated from Jeram Sanitary Landfill, Selangor, Malaysia in our previous study $[2,14]$. The $T$. obliquus UPSI-JRM02 culture was maintained in a $1 \mathrm{~L}$ Erlenmeyer flask in BG 11 medium. BG11 media was widely used for cyanobacteria [14]. The culture was illuminated with a cool white fluorescent lamp at 4000 lux light intensity and 12:12 light: dark photoperiod.

\subsection{Bioreactor Setup for Cultivation of T. obliquus UPSI-JRM02 under Nitrogen Stress}

The cultivation of $T$. obliquUs UPSI-JRM02 was conducted in a $2 \mathrm{~L}$ bioreactor with $1.4 \mathrm{~L}$ working volume (Biostat®Aplus, Sartorius AG, Germany). Figure 1 shows the schematic diagram of bioreactor used in this study. The bioreactor was inoculated with $5.5 \times 10^{6}$ cells $/ \mathrm{mL}$ of microalgae in BGll media without $\mathrm{NaNO}_{3}$ (O mg NaNO 3 ) and cultured for 14 days under nitrogen stress condition. Meanwhile, culture inoculated in BGll media with $400 \mathrm{mg}$ $\mathrm{NaNO}_{3}$ was used as a control. The cultivation of $T$. obliquus in both conditions was conducted at pH 9.8, $36{ }^{\circ} \mathrm{C}$ and 23500 lux of light intensity as obtained from our previous study [15]. The $\mathrm{pH}$ and temperature 
were controlled using $0.1 \mathrm{M} \mathrm{HCl}$ and $0.1 \mathrm{M} \mathrm{NaOH}$ and heat jacket, respectively. The light source was placed at the bottom of the bioreactor vessel. Filtered air was supplied by an air compressor (HiBlow Air Pump, Japan). A total of $35 \mathrm{~mL}$ of sample was collected every 2 days for cell growth $(2 \mathrm{~mL})$, biomass and biochemical $(30 \mathrm{~mL})$ and microscopy (3 $\mathrm{mL}$ ) analyses.

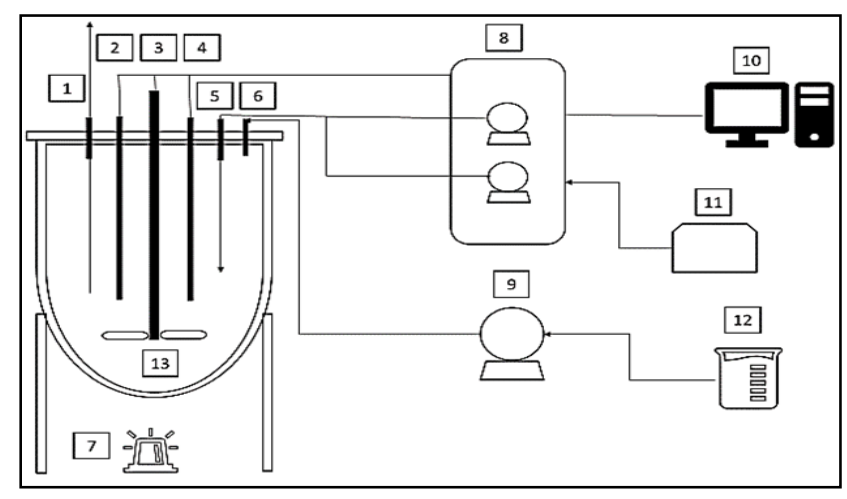

Figure 1 Schematic diagram of bioreactor used in the study. 1)Sampling port 2)Thermometer 3)Impeller 4)pH probe 5)Acid base inlet 6)Feed inlet 7)Light source 8)pH controller 9)Peristaltic pump 10)Computer 11)Air compressor 12)Influent tank 13)Vessel

\subsection{Cell Growth and Biomass Analysis}

The optical density of the microalgal cell was measured at $680 \mathrm{~nm}\left(\mathrm{OD}_{680}\right)$ using a visible spectrophotometer (Secomam Prim Visible Light Spectrophotometer, France). Meanwhile cell counts were performed using a haemocytometer with appropriate dilution. In addition, $30 \mathrm{~mL}$ of culture was harvested by centrifugation before being oven dried for 15 hours at $60^{\circ} \mathrm{C}$. The mass of the wet and dry samples was measured. A linear regression relationship between optical density and the dry mass of the microalgae was determined as in Equation 1

Biomass $=0.476 \times \mathrm{OD}_{680}-0.090$

$\left(R_{2}=0.994\right)$

The biomass productivity (mg/L/day) was calculated as described in Equation 2 [16]:

Biomass productivity = amount of biomass (mg/L) / Number of days

\subsection{Biochemical Analyses}

\subsubsection{Lipid}

The total lipid yield was extracted according to the protocol of Bligh and Dyer (1959) with some modification and measured gravimetrically (Li et al., 2015). For each sample, approximately $100 \mathrm{mg}$ of microalgal powder (W) was mixed with $2 \mathrm{~mL}$ of chloroform and $1 \mathrm{~mL}$ of methanol before incubation at room temperature for $24 \mathrm{~h}$. The mixture was then centrifuged at $4000 \times \mathrm{g}$ for $10 \mathrm{mins}$, before transferring the supernatant into a pre-weighed vial $\left(\mathrm{W}_{1}\right)$. The microalgal residue was then mixed with 1 $\mathrm{mL}$ of chloroform/methanol $(2: 1, \mathrm{v} / \mathrm{v})$ and centrifuged as described above. The supernatants were then dried in an oven at $70{ }^{\circ} \mathrm{C}$ until a constant weight $\left(W_{2}\right)$ achieved. The lipid content and lipid productivity were calculated as in Equations 3 [13] and 4 [16], respectively.

Total lipid $(\%$ dry weight $)=\left(\mathrm{W}_{1}-\mathrm{W}_{2}\right) / \mathrm{W} \times 100 \%$

Where $W_{1}$ is the initial weight and $W_{2}$ is the final weight.

Lipid productivity = biomass productivity (mg/L/day) $\mathrm{x}$ Lipid yield / 100

\subsubsection{Carbohydrate}

Carbohydrate yield was measured using phenolsulphuric acid method. Glucose solutions in the range of $0 \mathrm{mg} / \mathrm{L}$ to $100 \mathrm{mg} / \mathrm{L}$ were prepared to perform a standard curve. $5 \mathrm{mg}$ of lyophilised cells were suspended in $1 \mathrm{~mL}$ distilled water. The suspension was vortexed at maximum speed for $10 \mathrm{~min}$. The pigments were extracted using $80 \%$ pre-warmed ethanol at $60^{\circ} \mathrm{C}$ for $15 \mathrm{~min}$. The starch hydrolysis was conducted for three times using $60 \%$ perchloric acid and then incubated for $15 \mathrm{~min}$ at room temperature. After that, the sample was centrifuged for $15 \mathrm{~min}$ at $4000 \mathrm{rpm}$, the supernatant was then made up to 10 $\mathrm{mL}$. $1 \mathrm{~mL}$ of each sample was pipetted into a test tube followed by addition of $1 \mathrm{~mL}$ of $5 \%$ phenol. The sample was then added with $5 \mathrm{~mL}$ of $96 \% \mathrm{H}_{2} \mathrm{SO}_{4}$ and shaken well. After 10 mins the samples were vortexed and incubated in water bath for 20 mins at $25-30^{\circ} \mathrm{C}$. The absorbance was measured spectrophotometrically at $492 \mathrm{~nm}$ using a spectrophotometer [17]. The carbohydrate productivity was calculated as in Equation 5.

Carbohydrate productivity = Biomass productivity (mg/L/day)

x Carbohydrate content / 100

\subsubsection{Protein}

Protein analysis was conducted by using Pierce BCA Protein Assay Kit (Thermo Scientific, USA). Each sample and standard solution were pipetted into test tube containing $2 \mathrm{~mL}$ of working reagent. The samples were mixed well before incubated into water bath for $30 \mathrm{~min}$ at $60^{\circ} \mathrm{C}$. The samples were allowed to cool at room temperature before the absorbance measurement were taken at $562 \mathrm{~nm}$. The measurement of the absorbance needs to be done within 10 mins to avoid colour degradation. Working reagent was used as blank for this 
experiment. Total protein yield was determined using the protein standard curve and expressed as \%.

\subsubsection{Fatty Acid Methyl Ester (FAME)}

Twenty mg of dried microalgae biomass was trans methylated with $2.5 \mathrm{~mL}$ of methanol mixture and $2 \%$ (v/v) $\mathrm{H}_{2} \mathrm{SO}_{4}$ at $80^{\circ} \mathrm{C}$ for two and half hours. $1 \mathrm{~mL}$ of $\mathrm{n}$ hexane and $1 \mathrm{~mL}$ of saturated $\mathrm{NaCl}$ solution were added to the suspension after it cooled, forming separated layers in the tube. The upper hexane layer containing FAME was collected for gas chromatograph mass spectrometer (GC/MS) analysis. The GC/MS analysis was conducted with an Agilent 7890A gas chromatograph (GC) directly coupled to the mass spectrometer system (MS) of an Agilent 5975C inert MSD with a triple-axis detector. The Supelco 37 component FAME mix (Supelco, USA) was used as FAME standard. The analysis was performed with DB-5MS UI column (Agilent Tech., USA) and 5\% phenyl methylpolysiloxane at stationary phase. The GC/MSD Chemstation was used to determine all the peaks in the raw GC chromatogram. A library search was carried out for all peaks using the NIST/EPA/NIH version 2.0, and the results were combined in a single peak table.

To estimate the biodiesel properties, the iodine value (IV), saponification value (SV), cetane number $(\mathrm{CN})$, density, kinematic velocity $(\mathrm{KV})$, high heating value (HHV), degree of unsaturation (DU), long-chain saturated factor (LCSF), and cold filter plugging point (CFPP) were calculated according to the empirical equation [18, 19, 20 \& 21). The IV, SV, CN, density, In (KV) and HHV were determined by Equations 6-11, where $\mathrm{MW}$ is the molecular weight, $\mathrm{DB}$ is the number of double bond and $N$ is the percentage of each fatty acid component.

$$
\begin{aligned}
& \mathrm{IV}=\sum(560 \times \mathrm{N}) / \mathrm{MW} \\
& \mathrm{SV}=\sum(254 \times \mathrm{DB}) / \mathrm{MW} \\
& \mathrm{CN}=46.3+(5.458 / \mathrm{SV})-(0.225 \times \mathrm{IV}) \\
& \text { Density }=0.8463+\left(4.9 / \sum \mathrm{MW}\right)+\left(0.0118 \times \sum \mathrm{DB}\right) \\
& \text { In }(\mathrm{KV})=-12.503+\left(2.496 \times \sum \mathrm{MW}\right)-\left(0.178 \times \sum \mathrm{DB}\right) \\
& \mathrm{HHV}=49.43-(10)
\end{aligned}
$$

The DU was calculated based on Equation 12, where MUFA and PUFA is the weight percentage of monounsaturated fatty acid and polyunsaturated fatty acid (wt. \%).

$$
\text { DU }(\%)=\text { MUFA }+(2 \times \text { PUFA })
$$

The LCSF was estimated using Equation 13, which then was used to determine the CFPP in Equation 14. Both factors are related to chain saturation and the length of FAME.
$\operatorname{LCSF}=(0.1 \times \mathrm{C} 16)+(0.5 \times \mathrm{C} 18)+(1 \times \mathrm{C} 20)+(1.5 \times \mathrm{C} 22)$

$+(2 \times C 24)$

CFPP $=(3.1417 \times$ LCSF $)-16.477$

\subsection{Visualization of Lipid Body using Fluorescence Microscopy}

For fluorescence microscopy analysis, $1 \mathrm{~mL}$ of microalgae sample were harvested and centrifuged for $1 \mathrm{~min}$ at $10000 \mathrm{rpm}$. Cell were resuspended in a phosphate buffered saline (PBS). The sample was diluted accordingly to achieve OD750 below 1 so that the cell was not densely pack during observation and the cell can absorbed the stain well. Cells were stained with Nile red $(0.1 \mathrm{mg} / \mathrm{mL}$ Nile red in acetone) and incubated for 30 mins in the dark at room temperature. The stained cells were visualised by fluorescent microscope (Nicon Eclipse TE 2000-U, UK) and the image was viewed with NIS-Elements BR 3.0). Nile red stain were efficiently excited using G-2A (excitation 510-560 nm) using mercury lamp as broad-spectrum source. The samples were viewed under $1000 \mathrm{x}$ total magnification.

\subsection{Observation of Starch Granule and Lipid Body using Transmission Electron Microscopy (TEM)}

For TEM analysis, the cells were pelleted by centrifugation (4000 rpm), followed by fixing in $4 \%$ glutaraldehyde for 24 hours in $0.1 \mathrm{M}$ sodium cacodylate buffer. After washing three times in $0.1 \mathrm{M}$ sodium cacodylate buffer, the cells were then fixed with osmium tetroxide and cacodylate buffer (1:1) for 2 hours. The cells were washed and dehydrated in graded ethanol series from $35 \%$ to $100 \%(\mathrm{v} / \mathrm{v})$ and embedded in Epon resin. During semithin sectioning the sample was stained with Toludine Blue to determine for the appropriate area for ultrathin sectioning. The specimen was viewed under light microscope during this step. The specimen was cut using ultramicrotome and mounted on copper grid during ultrathin sectioning. The staining used for TEM microscopy was uranyl acetate and lead citrate. The micrograph was captured using (TEM Lio Libra 120, Zeiss, Oberkochen, Germany).

\subsection{Statistical Analysis}

The mean differences of lipid, carbohydrate and protein yields under nitrogen stress and control conditions were compared using Statistical Package for Social Sciences (SPSS) version 24 software. Independence t-test was used to determine the significance value for lipid and carbohydrate. Meanwhile, Mann-Whitney U test was used for protein as the data obtained were not normally distributed. A $p$ value less than 0.05 was considered significant. 


\subsection{RESULTS AND DISCUSSION}

3.1 Lipid, carbohydrate and protein yield under nitrogen stress condition

The lipid, carbohydrate and protein yields under nitrogen stress and control conditions were shown in Table 1 and Figure 2. In nitrogen stress condition the lipid yield increase from day $0(19 \%)$ to day 14 $(36.5 \%)$, while under the control lipid yield increased from day 0 (19\%) to day $8(30 \%)$ before decreasing to $28-25 \%$ afterward. In this study the lipid, carbohydrate and protein yields under nitrogen stress and the control were statistically analysed and compared (Table 1). It was found that, nitrogen stress condition showed higher lipid yield (28.53 \pm 0.70$)$ after 14 days, compared to the control $(25.56 \pm 1.26), t(35.95)=-$ 2.054, $P=0.047$. Hence, there is a significant difference in lipid yield under nitrogen stress and the control.

The carbohydrate yield increased from day 0 $(21 \%)$ to day 2 (23\%) before the yield decreased and reached $14 \%$ on day 14 . Meanwhile, the carbohydrate at controlled condition increased from day $0(22 \%)$ to day 4 (28\%) before dropped on day 6 $(19 \%)$ and onwards. There was homogeneity of variances for carbohydrate yield under nitrogen stress and controlled condition ( $p=0.832)$. This study found that, at nitrogen stress condition lower carbohydrate yield (18.75 \pm 0.59$)$ was obtained after 14 days, compared to the control $(22.04 \pm 0.61), \dagger(46)$ $=3.905, p=0.000$. Therefore, there is a significant difference in carbohydrate yield under nitrogen stress and the control. Protein yield reached to $50 \%$ on day 2 under nitrogen stress condition which is higher compared to the other biomolecule before decreasing to $33 \%$ on day 4 . Protein yield under controlled condition increased from day 0 (18\%) to day $6(43 \%)$ before decreasing on day 8 to day 14 . The statistical analysis of protein yield was conducted using Mann-Whitney $U$ test as the data obtained was not normally distributed. From the result obtained, it can be concluded that the protein yield under nitrogen stress and controlled conditions was not statistically significant $(U=239, p=0.312)$.

Table 1 Lipid, Carbohydrate and Protein Yields under Nitrogen Stress and Controlled Conditions

\begin{tabular}{|c|c|c|c|c|c|c|c|c|c|}
\hline \multirow{3}{*}{ Days } & \multicolumn{9}{|c|}{ Yield (\%) } \\
\hline & \multicolumn{2}{|l|}{ Lipid } & \multirow[t]{2}{*}{$p$} & \multicolumn{2}{|c|}{ Carbohydrate } & \multirow[t]{2}{*}{$p$} & \multicolumn{2}{|l|}{ Protein } & \multirow[t]{2}{*}{$p$} \\
\hline & Control & $\begin{array}{l}\text { Nitrogen } \\
\text { stress }\end{array}$ & & Control & $\begin{array}{l}\text { Nitrogen } \\
\text { stress }\end{array}$ & & Control & $\begin{array}{l}\text { Nitrogen } \\
\text { stress }\end{array}$ & \\
\hline 0 & $19 \pm 2.2$ & $19 \pm 2.3$ & $0.047^{*}$ & $22 \pm 0.8$ & $21 \pm 1.5$ & $0.000 *$ & $18 \pm 0.9$ & $44 \pm 1.1$ & 0.312 \\
\hline 2 & $22 \pm 1.3$ & $22 \pm 1.6$ & & $24 \pm 1.5$ & $23 \pm 2.4$ & & $22 \pm 2.2$ & $50 \pm 0.8$ & \\
\hline 4 & $25 \pm 1.2$ & $22 \pm 2.1$ & & $28 \pm 1.2$ & $20 \pm 3.1$ & & $36 \pm 1.6$ & $33 \pm 13$ & \\
\hline 6 & $28 \pm 3.2$ & $30 \pm 3.2$ & & $19 \pm 2.5$ & $19 \pm 1.1$ & & $43 \pm 2.1$ & $28 \pm 2.1$ & \\
\hline 8 & $30 \pm 0.9$ & $30 \pm 1.5$ & & $22 \pm 1.6$ & $18 \pm 1.5$ & & $38 \pm 3.1$ & $17 \pm 2.6$ & \\
\hline 10 & $28 \pm 2.2$ & $33 \pm 2.8$ & & $22 \pm 2.8$ & $17 \pm 1.9$ & & $36 \pm 2.7$ & $15 \pm 1.5$ & \\
\hline 12 & $27 \pm 1.4$ & $35 \pm 2.1$ & & $20 \pm 1.2$ & $16 \pm 1.7$ & & $20 \pm 2.1$ & $12 \pm 2.4$ & \\
\hline 14 & $25 \pm 1.7$ & $37 \pm 1.1$ & & $18 \pm 1.6$ & $14 \pm 2.1$ & & $12 \pm 1.1$ & $9 \pm 0.4$ & \\
\hline
\end{tabular}

Note. *Significant at probability level $p<0.05$

A study by Agirman and Cetin [22] shows that nitrogen stress decreased the cell growth and protein yield but increased the lipid yield as the carbon flow changes from synthesis of protein to lipid. It was believed that under nitrogen stress condition, the increase of lipid yield was due to carbon flow changes from protein to lipid synthesis. The reduction of protein yield under nitrogen stress condition is in accordance to the results obtained from this study. Based on Figure 2, carbohydrate trend was decreasing under nitrogen stress condition, which might be due to the partitioning of carbon towards TAG formation. It is believed that carbohydrates and lipid share the same fixed carbon. Figure 2 shows that the carbohydrate yield begins to decrease on day 4 . At the same time, the lipid yield was increased. A study by Benmoussa- Dahmen et al. [23] showed that carbohydrate synthesis was a faster method of energy storage compared to the lipid, hence the carbon was most likely to be allocated for the carbohydrate synthesis at early stages. The reason for this carbon allocation is glucose can be directly be converted into carbohydrate. In contrast, fatty acid biosynthesis is started in chloroplast which involved conversion of acetyl-CoA to malonyl-CoA [24].

It was found that during the first few days of nitrogen stress condition, total carbohydrate yields increased before decreasing few days after. At this time the total lipid yields also being increased. It is believed that the carbon partitioning under nitrogen stress condition is shifted from carbohydrate to neutral lipid including TAG as a secondary storage product. TAG is known as an energy-rich compound $(38.9 \mathrm{KJ} / \mathrm{g})$ and is more valuable compared to carbohydrate $(-17 \mathrm{KJ} / \mathrm{g}$ ) [25]. Due to the fact that lipid is an energy rich compound leading to the 
excess carbon being shifted from carbohydrate to lipid which resulted in carbohydrate degradation. Results of this study is in agreement to Li et al. [26] who reported that, after 2 days of nitrogen stress condition, the photosynthetically assimilated carbon flux was shifted from carbohydrate synthesis into fatty acid and neutral lipid synthesis.

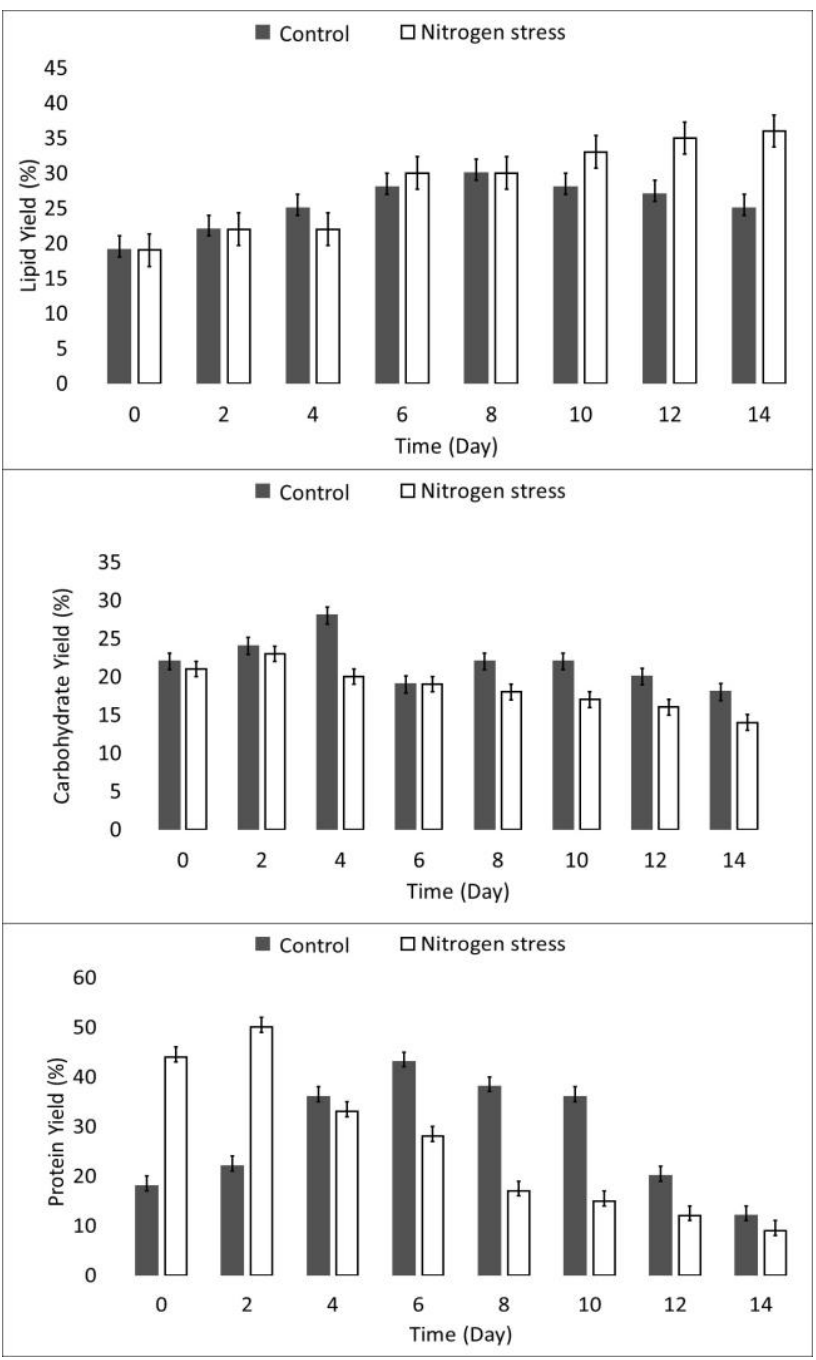

Figure 2 Lipid, carbohydrate and protein yields under nitrogen stress condition

In this study, under nitrogen stress condition the synthesis of protein and nucleic acid is no longer conducted, as the photosynthetic product is used for the synthesis of nitrogen free biomass constituent. When nitrogen concentration decreased, photosynthesis rate will be reduced and changed the microalgae metabolism from protein synthesis pathway to lipid or carbohydrate synthesis pathways.

3.2 Biomass, Lipid and Carbohydrate Productivity under Nitrogen Stress Condition

Nitrogen stress condition triggered different response in the biomass, lipid and carbohydrate productivity.
Some of the responses may have a negative impact on the others. For example, in this study, the biomass productivity under nitrogen stress condition is lower (74 mg/L/day) compared to the controlled condition (98 $\mathrm{mg} / \mathrm{L} /$ day) (Table 2). However, the lipid yield under nitrogen stress condition was slightly higher (37\%) compared to the lipid yield under controlled condition (25\%).

This result indicates that low lipid productivity was due to the less of biomass yield produced. Meanwhile, the carbohydrate productivity under nitrogen stress condition was low (12 mg/L/day) compared to the controlled condition (27 mg/L/day) (Table 2). Chu [3] stated that lipid yield increases under nitrogen stress condition, but production of biomass decreased under this situation which results in lower biomass productivity. This was proven in this study as biomass productivity under nitrogen stress condition was lower than controlled condition. However, due to lower nitrogen concentration, the carbon used for protein synthesis had been shifted to lipid synthesis causing the increase of lipid productivity as shown in Table 2.

Table 2 Lipid and Carbohydrate Productivity under Nitrogen Stress Condition

\begin{tabular}{lllll}
\hline Condition & \multicolumn{2}{l}{ Control } & \multicolumn{2}{l}{ Nitrogen stress } \\
\hline & $\begin{array}{l}\text { Yield } \\
(\%)\end{array}$ & $\begin{array}{l}\text { Productivity } \\
(\mathrm{mg} / \mathrm{L} / \text { day })\end{array}$ & $\begin{array}{l}\text { Yield } \\
(\%)\end{array}$ & $\begin{array}{l}\text { Productivity } \\
\text { (mg/L/day) }\end{array}$ \\
\hline Biomass & 22 & $98 \pm 2.2$ & 15 & $74 \pm 2.1$ \\
\hline Lipid & 25 & $25 \pm 1.5$ & 37 & $27 \pm 2.5$ \\
\hline Carbohydrate & 18 & $27 \pm 1.7$ & 16 & $12 \pm 1.9$ \\
\hline
\end{tabular}

\subsection{Visualization of Lipid Body using Fluorescence Microscopy}

Nitrogen stress condition accumulates large amounts of lipid mainly in the form of TAG. The lipid accumulation can be observed qualitatively by staining the cells with Nile red dye. In this study the lipid body was observed as yellow fluorescence when dyed with Nile red (Figure 3). It can be clearly observed that the lipid body in yellow fluorescence colour was increased from day 0 until day 14. This result is in accordance to the high lipid yield and productivity under nitrogen stress condition. Lipid body is the main site of neutral lipid storage in eukaryotic cells. The lipid body function as carbon and energy storage during unfavourable conditions, acyl chains storage site for membrane synthesis, and plays few roles in cellular physiology [27]. The main composition of lipid body is TAG, which is suitable as biofuel feedstock.

3.4 Observation of Starch Granule and Lipid Body under TEM

Figure 4 shows lipid body and starch granule from TEM image of $T$. obliquus cell cultivated under 
nitrogen stress condition. Lipid body and starch granule acts as the most important energy reserve in microalgae.
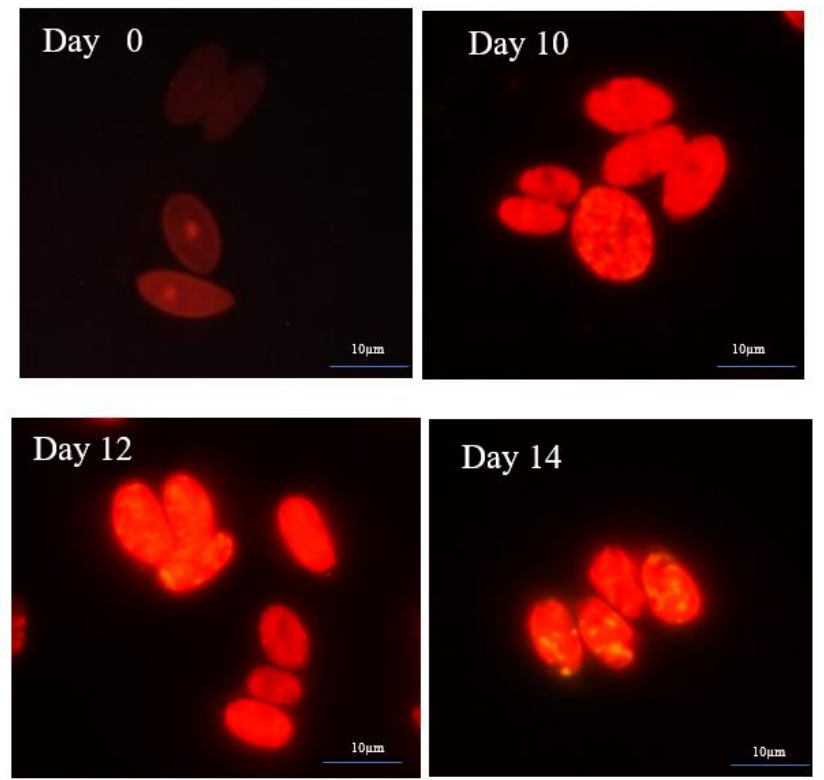

Figure 3 Changes in lipids accumulation during nitrogen stress condition of $T$. obliquus. Lipid bodies were stained using Nile red and emit yellow fluorescence. Magnification 1000X

The TEM image taken on day 14 of nitrogen stress condition reveals the presence of high lipid bodies compared to the starch granules. According to Zhu, Li and Hiltunen [28] nitrogen depletion condition initially caused microalgae to store carbohydrate for the first few days then oil accumulation was triggered causing the decrease of starch and inhibit the growth of microalgae cells during this condition. A study by Li et al. [13] stated that lipid synthesis is mostly dependent on starch degradation, and study conducted on C. sorokiniana cells proved the carbon flow rerouted from carbohydrate synthesis towards lipid under nitrogen stress condition.

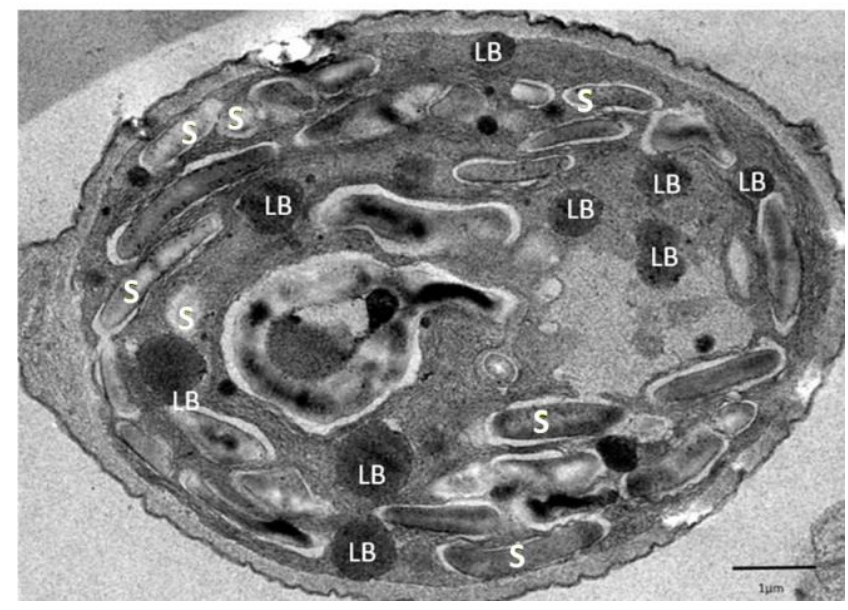

Figure 4 TEM image of $T$. obliquus under nitrogen stress condition at day 14. Magnification 20000x. LB, lipid body; S, starch

\subsection{Composition of FAME and Biodiesel Properties}

Biodiesel properties are influenced by the fatty acid composition of the feedstock oil. The fatty acid of $T$. obliquus under nitrogen stress condition was analysed to investigate the compatibility of the FAME produced for biodiesel application. The FAME profile of $T$. obliquus analysed by GC/MS was presented in Table 3.

Table 3 Fatty Acid Profile of T. Obliquus by GCMS

\begin{tabular}{|c|c|c|c|}
\hline Common name & $\begin{array}{l}\text { Lipid } \\
\text { number }\end{array}$ & Type & FAME (\%) \\
\hline Palmitic acid & C16:0 & SFA & 43.33 \\
\hline Linolenic acid & C18:3 & PUFA & 29.36 \\
\hline $\begin{array}{l}8,11- \\
\text { Octadecadienoi } \\
\text { c acid } \\
7,10-\end{array}$ & C18:2 & PUFA & 17.66 \\
\hline $\begin{array}{l}\text { Hexadecadienoic } \\
\text { acid }\end{array}$ & C16:2 & PUFA & 7.05 \\
\hline Palmitoleic acid & C16:1 & MUFA & 2.13 \\
\hline Oleic acid & C18:1 & MUFA & 0.47 \\
\hline
\end{tabular}

The most abundant fatty acid composition in $T$. obliquus were palmitic acid (C16:0) with a composition of more than $43.33 \%$ followed by linolenic acid (C18:3) with 29.36\%, 8,11octadecadienoic acid (17.66\%), 7,10hexadecadienoic acid $(7.05 \%)$ palmitoleic acid $(2.13 \%)$ and oleic acid $(0.47 \%)$. The total saturated fatty acid (SFA) obtained in this study was $43.33 \%$ while the PUFA was $54.07 \%$, and the lowest yield attained was monounsaturated fatty acid (MUFA) at only $2.6 \%$. This study is in accordance to Chen et al. [29] where the highest content of fatty acids reported were palmitic, stearic, oleic, linoleic, and linolenic acid (C16 to C18). A study by Sharmin et al. [30] stated that the most profound fatty acid found is palmitic acid, which is in agreement with our findings. Similar results were also reported by Yang et al. [8] where they found the most dominant fatty acid were palmitic and oleic acid. Venkata \& Devi [31] in their study stated that lipid synthesis occurred in four stepprocesses. The first step was lipid accumulation inside cell, followed by formation of acetyl-CoA and malonyl-CoA. The third step was the synthesis of palmitic acid and the fourth step is the synthesis of higher fatty acid by chain elongation. The findings from Venkata et al. (2014) explain the high content of palmitic acid obtained in our study.

Another study by Jena et al. [32] reported that there was a significant amount of palmitic acid (19.5$30.3 \%$ ) in Chlorococcum sp., Chlorella sp., and Scendesmus sp. The composition of biodiesel from this study was comprised of $43.33 \%$ SFA and $54.07 \%$ PUFA. SFA is more suitable for the usage in temperate weather country due to the lack of double bond, causing the biodiesel to have higher oxidative 
stability. In contrast, biodiesel with higher PUFA content is mostly used in cold weather country as they have lower oxidative stability due to the presence of a double bond. But, compared to SFA, the PUFA possess higher melting point. For biodiesel application, the fatty acid mixture can be separated into two different friction of saturated and unsaturated fatty acid by using different industrial methods based on fatty acid properties or by using an organic solvent to improve the phase separation [33]. Once the fatty acid mixture was separated, it can be utilised as biofuel feedstock according to the temperature suitability. The temperature for temperate and cold weather countries were reported in the range of 10 to $22^{\circ} \mathrm{C}$ and -3 to $10^{\circ} \mathrm{C}$ respectively [34. 35].

Biodiesel properties are essential factors to determine its suitability for engine performance and emission. The most important properties that influence the utilization of biodiesel fuels are, cetane number, viscosity, higher heating value, and density as they determined the fuel quality while providing the input data for predictive engine combustion model [20]. Table 4 shows the biofuel properties of $T$. obliquus in comparison to EN 14214 (European) and ASTM D6751 (United State). In general, the biofuel properties obtained under nitrogen stress condition was within the range of biodiesel standard, making it suitable to be used in cold weather country.

Table 4 Biofuel Properties of T. obliquus

\begin{tabular}{|c|c|c|c|c|}
\hline Property & $\begin{array}{l}\text { EN } \\
14214\end{array}$ & $\begin{array}{l}\text { ASTM } \\
\text { D6751 }\end{array}$ & Control & $\begin{array}{l}\text { Nitrogen } \\
\text { stress }\end{array}$ \\
\hline $\begin{array}{ll}\text { IV } & (\mathrm{g} \\
\left.\mathrm{I}_{2} / 100 \mathrm{~g}\right)\end{array}$ & $<130$ & - & $122.68 \pm 1.21$ & $102.07 \pm 3.74$ \\
\hline SV & $<120$ & - & $206.07 \pm 4.36$ & $210.12 \pm 3.84$ \\
\hline $\mathrm{CN}$ & $>51$ & $>47$ & $45.18 \pm 1.84$ & $49.30 \pm 0.33$ \\
\hline DU & - & - & $124.18 \pm 3.48$ & $110.74 \pm 3.52$ \\
\hline LCSF (\%) & - & - & $3.791 \pm 1.54$ & $4.33 \pm 0.88$ \\
\hline CFPP $\left({ }^{\circ} \mathrm{C}\right)$ & $\begin{array}{l}\leq 5 / \leq- \\
20\end{array}$ & - & $-4.56 \pm 0.93$ & $-2.86 \pm 1.57$ \\
\hline $\begin{array}{l}\text { Density } \\
\text { (kg/L) }\end{array}$ & $\begin{array}{l}860- \\
900\end{array}$ & - & $910 \pm 0.42$ & $940 \pm 2.39$ \\
\hline KV at & 3.5 & 1.9 & & \\
\hline $\begin{array}{l}40^{\circ} \mathrm{C} \\
\left(\mathrm{mm}^{2} / \mathrm{s}\right)\end{array}$ & 5.0 & 6.0 & $3.31 \pm 0.86$ & $4.55 \pm 0.72$ \\
\hline $\begin{array}{l}\mathrm{HHV} \\
(\mathrm{MJ} / \mathrm{kg})\end{array}$ & - & - & $41.31 \pm 3.59$ & $45.28 \pm 1.57$ \\
\hline $\begin{array}{l}\text { Flash } \\
\left.\text { point ( }{ }^{\circ} \mathrm{C}\right)\end{array}$ & $>120$ & $>93$ & $210.21 \pm 4.2$ & $232.52 \pm 5.6$ \\
\hline
\end{tabular}

\subsection{CONCLUSION}

From this study it can be concluded that lipid yield and productivity were significantly higher under nitrogen stress condition than the control. It was found that the carbohydrate and protein content decreased after 4 days of culture period, indicating that the fixed carbon was shifted towards lipid synthesis. The properties of biodiesel produced by $T$.
obliquUs UPSI-JRM02 under nitrogen stress condition complied with the biodiesel standard and demonstrated the suitable biodiesel properties for application in cold weathered country. Therefore, $T$. obliquUs UPSI-JRM02 can be a promising biodiesel feedstock for future biomass energy application.

\section{Acknowledgement}

The authors wish to thank the Ministry of Higher Education (MOHE) for financing this study through the Fundamental Research Grant Scheme (Code: FRGS/1/2015/SG05/UPSI/02/1). We are also grateful to Makmal Pencirian Struktur Molekul (MPSM) at the Centre for Research and Instrumentation Management (CRIM), Universiti Kebangsaan Malaysia (UKM) for their technical assistance.

\section{References}

[1] Suparmaniam, U., Lam, M., Uemura, Y., Lim, J., Lee, K., \& Shuit, S. 2019. Insights into the Microalgae Cultivation Technology and Harvesting Process for Biofuel Production: A Review. Renewable and Sustainable Energy Reviews. 115: 109361. Doi: 10.1016/j.rser.2019.109361.

[2] Nordin, N., Yusof, N., \& Samsudin, S. 2017. Biomass Production of Chlorella sp., Scenedesmus sp., and Oscillatoria sp. in Nitrified Landfill Leachate. Waste and Biomass Valorization. 8(7): 2301-231 1. Doi: 10.1007/s12649016-9709-8.

[3] Chu, W. 2017. Strategies to Enhance Production of Microalgal Biomass and Lipids for Biofuel Feedstock. European Journal of Phycology. 52(4): 419-437. Doi: 10.1080/09670262.2017.1379100.

[4] Brever, G., Lamers, P., Martens, D., Draaisma, R., \& Wijffels, R. 2013. Effect of Light Intensity, pH, and Temperature on Triacylglycerol (TAG) Accumulation Induced by Nitrogen Starvation in Scenedesmus obliquus. Bioresource Technology. 143: 1-9. Doi: 10.1016/j.biortech.2013.05.105.

[5] Stephenson, A., Dennis, J., Howe, C., Scott, S., \& Smith, A. 2010. Influence of Nitrogen-Limitation Regime on the Production by Chlorella vulgaris of Lipids for Biodiesel Feedstocks. Biofuels. 1 (1): 47-58. Doi: 10.4155/bfs.09.1.

[6] Chellamboli, C., \& Perumalsamy, M. 2014. Application of Response Surface Methodology for Optimization of Growth and Lipids in Scenedesmus abundans using Batch Culture System. RSC Adv. 4(42): 22129-22140. Doi: 10.1039/c4ra01179a.

[7] Martin, G. J. O., Hill, D. R. A., Olmstead, I. L. D., Bergamin, A., Shears, M. J., Dias, D. A., \& Callahan, D. L. 2014. Lipid Profile Remodelling in Response to Nitrogen Deprivation in the Microalgae Chlorella sp. (Trebouxiophyceae) and Nannochloropsis sp. (Eustigmatophyceae). PLOS ONE. 9(8). Doi: 10.1371/journal.pone.0103389.

[8] Yang, F., Long, L., Sun, X., Wu, H., Li, T., \& Xiang, W. 2014 Optimization of Medium Using Response Surface Methodology for Lipid Production by Scenedesmus sp. Marine Drugs. 12(3): 1245-1257. Doi: 10.3390/md12031245.

[9] Markou, G., Angelidaki, I., Georgakakis, D. 2012. Microalgal Carbohydrates: An Overview of the Factors Influencing Carbohydrates Production, and of Main Bioconversion Technologies for Production of Biofuels. Applied Microbiology and Biotechnology. 96(3): 631-645. Doi: 10.1007/s00253-012-4398-0.

[10] Fulbright, S. P., Robbins-Pianka, A., Berg-Lyons, D., Knight, R., Reardon, K. F., \& Chisholm, S. T. 2018. Bacterial 
Community Changes in an Industrial Algae Production System. Algal Research. 31: 147-156.

Doi: 10.1016/j.algal.2017.09.010.

[11] Parsa, M., Jalilzadeh, H., Pazoki, M., Ghasemzadeh, R., \& Abduli, M. A. 2018. Hydrothermal Liquefaction of Gracilaria gracilis and Cladophora glomerata macroAlgae for Biocrude Production. Bioresource Technology. 250: 26-34. Doi: 10.1016/j.biortech.2017.10.059.

[12] Lee, O., Seong, D., Lee, C., Lee, E. 2015. Sustainable Production of Liquid Biofuels from Renewable Microalgae Biomass. Journal of Industrial and Engineering Chemistry. 29: 24-31. Doi: 10.1016/j.jiec.2015.04.016.

[13] Li, L., Cui, J., Liu, Q., Ding, Y., Liu, J. 2015. Screening and Phylogenetic Analysis of Lipid-Rich Microalgae. Algal Research. 11: 381-386. Doi: 10.1016/j.algal.2015.02.028.

[14] Nordin, N., Yusof, N., \& Samsudin, S. 2014. Microalgae Biomass Production and Nitrate Removal from Landfill Leachate. Proceeding of International Conference on Research, Implementation and Education of Mathematics and Sciences 2014. Yogyakarta: Yogyakarta State University.

[15] Nordin, N., Samsudin, S., \& Yusof, N. 2019. Isolation and Identification of Microalgae from High Nitrate Landfill Leachate. Jurnal Teknologi. 81(5): 61-67. Doi: https://doi.org/10.11113/jt.v81.13581.

[16] Singh, P., Guldhe, A., Kumari, S., Rawat, I., Bux, F. 2015. Investigation of Combined Effect of Nitrogen, Phosphorus and Iron on Lipid Productivity of Microalgae Ankistrodesmus falcatus KJ671624 using Response Surface Methodology. Biochemical Engineering Journal. 94: 22-29. Doi: 10.1016/j.bej.2014.10.019.

[17] Zhu, S., Huang, W., Xu, J., Wang, Z., Xu, J., Yuan, Z. 2013. Metabolic Changes of Starch and Lipid Triggered by Nitrogen Starvation in the Microalga Chlorella zofingiensis. Bioresource Technology. 152: 292-298. Doi: 10.1016/j.biortech.2013.10.092.

[18] Francisco, É., Neves, D., Jacob-Lopes, E., \& Franco, T. 2010. Microalgae as Feedstock for Biodiesel Production: Carbon Dioxide Sequestration, Lipid Production and Biofuel Quality. Journal of Chemical Technology \& Biotechnology. 85(3): 395-403. Doi: 10.1002/jctb.2338.

[19] Ramos, M. J., Fernández, C. M., Casas, A., Rodríguez, L., \& Pérez, Á. 2009. Influence of Fatty Acid Composition of Raw Materials on Biodiesel Properties. Bioresource Technology. 100(1): 261-268. Doi: 10.1016/j.biortech.2008.06.039.

[20] Ramírez-Verduzco, L., Rodríguez-Rodríguez, J., \& JaramilloJacob, A. 2012. Predicting Cetane Number, Kinematic Viscosity, Density and Higher Heating Value of Biodiesel from Its Fatty Acid Methyl Ester Composition. Fuel. 91(1): 102-111. Doi: 10.1016/j.fuel.201 1.06.070.

[21] Wu, H., \& Miao, X. 2014. Biodiesel Quality and Biochemical Changes of Microalgae Chlorella pyrenoidosa and Scenedesmus obliquus in Response to Nitrate Levels. Bioresource Technology. 170: 421-427. Doi: 10.1016/j.biortech.2014.08.017.

[22] Agirman, N., \& Cetin, A. 2017. Effect of Nitrogen Limitation on Growth, Total Lipid Accumulation and Protein Amount in Scenedesmus acutus as Biofuel Reactor Candidate.
Natural Science and Discovery. 3(3): 33-38. Doi: $10.20863 /$ nsd.322614.

[23] BenMoussa-Dahmen, I., Chtourou, H., Rezgui, F., Sayadi, S., \& Dhouib, A. 2016. Salinity Stress Increases Lipid, Secondary Metabolites and Enzyme Activity in Amphora subtropica and Dunaliella sp. for Biodiesel Production. Bioresource Technology. 218: 816-825. Doi: 10.1016/j.biortech.2016.07.022.

[24] Subramanian, V., Dubini, A., \& Seibert, M. 2012. Metabolic Pathways in Green Algae with Potential Value for Biofuel Production. Cellular Origin, Life in Extreme Habitats and Astrobiology. Switzerland: Springer.

[25] Klass, D. 2007. Biomass for Renewable Energy, Fuels, and Chemicals. San Diego: Academic Press.

[26] Li, Y., Han, D., Sommerfeld, M., \& Hu, Q. 2011. Photosynthetic Carbon Partitioning and Lipid Production in the Oleaginous Microalga Pseudochlorococcum sp. (Chlorophyceae) under Nitrogen-limited Conditions. Bioresource Technology. 102(1): 123-129. Doi: 10.1016/j.biortech.2010.06.036.

[27] Goold, H., Beisson, F., Peltier, G., \& Li-Beisson, Y. 2014 Microalgal Lipid Droplets: Composition, Diversity, Biogenesis and Functions. Plant Cell Reports. 34(4): 545555. Doi: 10.1007/s00299-014-1711-7.

[28] Zhu, L., Li, Z., Hiltunen, E. 2016. Strategies for Lipid Production Improvement in Microalgae as a Biodiesel Feedstock. Biomed Research International. 2016: 8792548. Doi: 10.1155/2016/8792548.

[29] Chen, Z., Wang, L., Qiu, S., \& Ge, S. 2018. Determination of Microalgal Lipid Content and Fatty Acid for Biofuel Production. BioMed Research International. 2018: 1-17. Doi: 10.1155/2018/1503126.

[30] Sharmin, T., Monirul Hasan, C., Aftabuddin, S., Rahman, M., \& Khan, M. 2016. Growth, Fatty Acid, and Lipid Composition of Marine Microalgae Skeletonema costatum Available in Bangladesh Coast: Consideration as Biodiesel Feedstock. Journal of Marine Biology. 2016: 6832847. DOI: 10.1155/2016/6832847.

[31] Venkata Mohan, S., \& Devi, M.P. 2014. Salinity Stress Induced Lipid Synthesis to Harness Biodiesel during Dual Mode Cultivation of Mixotrophic Microalgae. Bioresource Technology. 165: 288-294. Doi: 10.1016/j.biortech.2014.02.103.

[32] Jena, J., Nayak, M., Panda, H., Pradhan, N., Sarika, C., \& Panda, P. et al. 2012. Microalgae of Odisha Coast as a Potential Source for Biodiesel Production. World Environment. 2(1): 11-16. Doi:10.5923/j.env.20120201.03.

[33] Haraldsson, G. 1984. Separation of Saturated/unsaturated Fatty Acids. Journal of the American Oil Chemists' Society. 61 (2): 219-222. Doi: 10.1007/bf02678772.

[34] Spaargaren, O. C., \& Deckers J. A. 2005. Factors of Soil Formation/Climate. Amsterdam: Elsevier.

[35] Varma, M., Gupta, A., Ghosal, P., \& Majumder, A. 2021. A Review on Performance of Constructed Wetlands in Tropical and Cold Climate: Insights of Mechanism, Role of Influencing Factors, and System Modification in Low Temperature. Science of The Total Environment. 755: 142540. Doi: 10.1016/j.scitotenv.2020.142540. 